\title{
Implementation of Corporate Absolute Responsibility for Land fires Causing Air Pollution
}

\author{
Rony Andre Christian Naldo \\ Ph.D. in Law Program, Graduate School \\ University of North Sumatera \\ Medan, North Sumatra, Indonesia \\ ronyandre87@gmail.com
}

\author{
Ningrum Natasya Sirait \\ Ph.D. in Law Program, Graduate School \\ University of North Sumatera \\ Medan, North Sumatra, Indonesia \\ ningrum.sirait@gmail.com
}

\begin{abstract}
Corporate activities in forest and plantation exploration are related to the environment issue. Indonesian Law Number 32 the year of 2009 concerning Environmental Protection and Management, article 68 point $B$ stated that in conducting its business activities, it has an obligation to maintain the sustainability of environmental functions. Fires on corporate land causing pollution must be managed with Absolute Corporate Responsibility (ACR).
\end{abstract}

This paper will discuss on the rationality on applying the ACR due to land fires that cause pollution. Furthermore, it describes the benefits of applying the ACR as the effect of land fires the which cause pollution.

This research is a normative legal research Juridical normative approach method used to analyze various laws and regulations related to the ACR due to land pollution causing fires.

As a conclusion, the application of the ACR due to land fires that cause pollution is a way to respect the principles of human rights in environmental issues by maintaining the sustainability of ecological functions. Furthermore, it is the implementation of the mandatory principles of polluters that have determined to Article 2 point $A$ and $J$ of Indonesia Law Number 32 The year 2009. Benefits of applying the ACR as the effect of land fires the which cause pollution are every corporate performing its obligations to maintain the sustainability of environmental functions, as well as with corporate compensation provided by the government can recover the situation of Contaminated people and environment.

\section{Keywords-Responsibility; Cooperation; Pollution}

\section{INTRODUCTION}

Law is a political product established by the Government to regulate the life of the people, by its very nature of governing and forcing. With the law, it is expected to create justice, legal certainty, the benefit/happiness, truth, peace, order, and prosperity in people's lives.

Law forms and develops as a product that encompasses all fields in people's lives [1]. Legal development is affected by culture, history, and Also time. Therefore, the law should not be static, but the law must be dynamic [2]. The law controls justice, where justice must fulfill the values; Equality before the law, human rights, truth, obedience, and protecting society [3].
Article 1 Paragraph (3) of the 1945 Constitution of the Republic of Indonesia (1945) provides that: "Indonesia is a state of law." A good and healthy environment is a human right and also constitutes a constitutional right guaranteed by the Government for all Indonesian Citizens (citizen) [4].

In carrying out sustainable development, the Government and all concerned parties must protect the environment, so that the environment can still be a life support for all citizens and other sentient beings.

In Indonesia, many corporations whose business operations are closely related to the environment [5]. Business activities undertaken by the companies are closely linked to the environment, among others, are the exploitation of forest land and plantations.

Based on the provision of Article 68 Sub-Article b of Law Number 32 Year 2009 regarding Environmental Protection and Management (Law Number 32 Year 2009), in conducting its business activities, the corporation is obliged to maintain the sustainability of environmental functions by Preventing the occurrence of pollution that exceeds the standard of damage [6].

In the case of corporate forestry and real cultivation activities, there are a variety of corporations burned. Land fires that have occurred certainly result in environmental pollution [7]. In many cases, the pollution that has occurred, fires of corporations exceeds the standard criteria of damage, the which of course causes environmental damage [8].

The presence of contamination that goes beyond the standard criteria of environmental damage in the resulting harm raises absolute responsibility for the corporation, this can be emphasized in accordance with the provisions of Article 88 of Law Number 32 the year 2009, and Article 49 of Law Number 41 Year 1999 concerning Forestry (Law Number 41 Year 1999) [9].

PT. National Sago Prima (PT NSP) is one of the Several corporations based on the civil lawsuit of the Ministry of Environment and Forestry (KLHK) sentenced South Jakarta District Court (PN) in August 2016 to pay compensation of Rp. 1,040,000,000,000- (one trillion forty billion Rupiahs) to the KLHK for errors in the form of Negligence land that the caused fire in Meranti Islands, Riau Province, in 2015 ago.

Judged by the Civil Law, the occurrence of fires of corporations that cause pollution that exceeds the standard criteria of damage the resulting in environmental damage, of 
course, is the Act against the Law, where one of the elements that must be proven is certainly an element of error, affirmed that there is actually disharmony about the element of mistakes between the provisions of Article 88 of Law Number 32 Year 2009 and Article 49 of Law Number 41 Year 1999 with elements of Act against the Law based on the provisions of Article 1365 of the Civil Code (Civil Code ) regarding the absolute liability for the resulting corporations land from the occurrence of fires that cause pollution to exceed the standard criteria of environmental damage in the resulting damage [10].

Further Examined under the provisions of Article $28 \mathrm{D}$ Paragraph (1) of the 1945 Constitution, the application of absolute responsibility for corporations pursuant to Article 88 of Law Number 32 Year 2009 and Article 49 of Law Number 41 Year 1999 as a result of land fires that cause pollution that exceeds the standard criteria of the resulting damage in Environmental damage, Cleary is a legal norm that does not a accommodate the principle of fair legal certainty [11].

\section{PROBLEMS}

The problems of this research are; What is the rationale and benefits of applying absolute responsibility to the corporation due to the occurrence of fires causing land pollution.

\section{RESEARCH METHODOLOGY}

This study used a type of normative legal research [12]. The method used is the normative Juridical method [13]. This research is analytical descriptive. This research of data is like a normative law research, that is using the data secondary either in the form of primary, secondary, and tertiary legal material as the main data/research subject [14].

Data collection is performed through library research study, i.e., the collection of data document, literature and studying the provisions of legislation related to the issues to be answered the in this study.

All the information that has been obtained and collected will then be reviewed restaurants and Analyzed qualitatively. Described then again to be presented systematically, the resulting in a discussion that can be used to answer the problems in this study.

\section{DISCUSSION}

Indonesia is a right country. The legal state in question is recht staat. Elements of recht staat: first, recognition and protection of human rights; Second, the state are based on Trias Politica; Third, the government builds on the law (wegmatigeheid van bestuur); Fourthly, there is an administrative court authorized for cases of unlawful acts committed by the Government [15].

By the provisions of Article $28 \mathrm{H}$ paragraph (1) of the 1945 Constitution, a good and healthy environment is a human right and constitutional right of all citizens. Consequently, everyone is obliged to preserve the environment by Preventing and Preventing damage and pollution.

In Indonesia, many corporations Whose business operations are closely related to the environment. Business activities undertaken are closely linked to the environment, among others, are the exploitation of forest land and plantations.

Based on the provisions of Article 68 letter b Law Number 32 The year 2009, in conducting its business activities, the corporation is obliged to maintain the sustainability of environmental functions by Preventing the occurrence of pollution that exceeds the standard criteria of damage, the which in fact leads to environmental damage.

Facts that exist in Indonesia, in the case of the implementation of forest and plantation operations, there is many corporate land on fire. Land fires that occur certainly result in environmental pollution. In many cases of pollution the caused by fires in corporate lands, pollution exceeds the standard criteria of Destruction roommate certainly causes environmental damage.

Regarding the standard criteria of general damage due to land fires can be seen in various tables, as follows:

Table 1. General Criteria Mineral Raw Land Damage Associated With Fire Land. Source Provided by Government Regulation No. 4 of 2001 on Damage Control and Environmental Pollution Associated With Fires and/or Land (PP No. 4, 2001).

\begin{tabular}{|c|c|c|c|}
\hline \multicolumn{4}{|c|}{ THE PHYSICAL PROPERTIES OF LAND } \\
\hline No & Parameter & The Damage & $\begin{array}{l}\text { measurement } \\
\text { Method }\end{array}$ \\
\hline 1 & Soil structure & $\begin{array}{l}\text { 1. Soil structure damage } \\
\text { occurred; } \\
\text { 2. Water infiltration } \\
\text { Down; } \\
\text { 3. Plant Roots Not } \\
\text { Evolving; } \\
\text { 4. The increasing rate of } \\
\text { soil erosion. }\end{array}$ & $\begin{array}{l}\text { Direct observation } \\
\text { (Visual). }\end{array}$ \\
\hline 2 & Porosity & $\begin{array}{l}\text { 1. Decreased occurrence } \\
\text { of porosity; } \\
\text { 2. Decreased infiltration; } \\
\text { 3. The increased flow of } \\
\text { surface; } \\
\text { 4. Availability of Air and } \\
\text { Water To Reduce } \\
\text { Crop. }\end{array}$ & $\begin{array}{l}\text { Weight Calculation } \\
\text { Of Moisture } \\
\text { Content and } \\
\text { Maximum } \\
\text { Capacity } \\
\text { Retention. }\end{array}$ \\
\hline 3 & $\begin{array}{l}\text { Fill weights ( } \mathrm{g} / \\
\mathrm{cm}^{3} \text { ) }\end{array}$ & $\begin{array}{l}\text { 1. Compaction occurs; } \\
\text { 2. Plant Roots Not } \\
\text { Evolving; } \\
\text { 3. Availability of Air and } \\
\text { Water To Reduce } \\
\text { Crop. }\end{array}$ & $\begin{array}{l}\text { Ring Plate - } \\
\text { Gravimetry. }\end{array}$ \\
\hline 4 & $\begin{array}{l}\text { Available Water } \\
\text { Content }(\%)\end{array}$ & $\begin{array}{l}\text { 1. The decline occurred } \\
\text { Moisture; } \\
\text { 2. Declining Soil Water } \\
\text { Holding Capacity; } \\
\text { 3. Water Shortage plants. }\end{array}$ & $\begin{array}{l}\text { Pressure Plate - } \\
\text { Gravimetry. }\end{array}$ \\
\hline 5 & $\begin{array}{l}\text { Potential } \\
\text { development } \\
\text { and contracting }\end{array}$ & $\begin{array}{l}\text { 1. Losing ground Inflate } \\
\text { properties; } \\
\text { 2. Increasing the rate of } \\
\text { erosion. }\end{array}$ & COLE. \\
\hline 6 & $\begin{array}{l}\text { Soil penetration } \\
\left(\mathrm{kg} / \mathrm{cm}^{2}\right)\end{array}$ & $\begin{array}{l}\text { 1. Soil Penetration } \\
\text { Rises; } \\
\text { 2. Water infiltration } \\
\text { Down; } \\
\text { 3. Plant Roots Not } \\
\text { Evolving. }\end{array}$ & Penetrometer. \\
\hline 7 & $\begin{array}{l}\text { consistency } \\
\text { Land }\end{array}$ & $\begin{array}{l}\text { 1. Losing ground cure } \\
\text { plastic; } \\
\text { 2. The rate of erosion } \\
\text { Rises }\end{array}$ & Piridan hand. \\
\hline
\end{tabular}


Table 1, cont.

\begin{tabular}{|c|c|c|c|}
\hline \multicolumn{4}{|c|}{ CHEMICAL SOIL PROPERTIES } \\
\hline No & Parameter & Damage Occurred & $\begin{array}{l}\text { Measurement } \\
\text { methods }\end{array}$ \\
\hline 1 & $\begin{array}{l}\text { C - Organic } \\
(\%)\end{array}$ & $\begin{array}{l}\text { 1. Organic C- Levels } \\
\text { Down; } \\
\text { 2. Soil Fertility Decline; } \\
\text { 3. Influential Against Soil } \\
\text { Physical Properties. }\end{array}$ & $\begin{array}{l}\text { Walkey and Black } \\
\text { or the CHNS } \\
\text { Elementary } \\
\text { Analysis Tool. }\end{array}$ \\
\hline 2 & N Total (\%) & $\begin{array}{l}\text { 1. Levels of N Total Down; } \\
\text { 2. Soil Fertility Decline. }\end{array}$ & $\begin{array}{l}\text { Kjeldahl or the } \\
\text { CHNS Elementary } \\
\text { Analysis Tool. }\end{array}$ \\
\hline a & $\begin{array}{l}\text { Ammonium } \\
(\mathrm{ppm})\end{array}$ & $\begin{array}{l}\text { 1. Ammonium levels are } \\
\text { down; } \\
\text { 2. Soil Fertility Decline. }\end{array}$ & $\begin{array}{l}\text { Kjeldahl or } \\
\text { Specific Electrodes } \\
\text { or Autoanalisator. }\end{array}$ \\
\hline $\mathrm{b}$ & Nitrate (ppm) & $\begin{array}{l}\text { 1. Nitrate Levels Rise; } \\
\text { 2. Groundwater poison. }\end{array}$ & $\begin{array}{l}\text { Kjeldahl or } \\
\text { Specific Electrodes } \\
\text { or Autoanalisator. }\end{array}$ \\
\hline 3 & $\mathrm{P}(\mathrm{ppm})$ & $\begin{array}{l}\text { 1. Available P content Up; } \\
\text { 2. Nutrient balance } \\
\text { Impaired. }\end{array}$ & $\begin{array}{l}\text { Spectrophotometer } \\
\text { or Autoanalisator. }\end{array}$ \\
\hline 4 & $\mathrm{pH}$ & $\begin{array}{l}\text { 1. } \mathrm{pH} \text { goes up or down; } \\
\text { 2. Nutrient balance } \\
\text { Impaired. }\end{array}$ & PH meter. \\
\hline 5 & $\begin{array}{l}\text { Electrical } \\
\text { conductivity } \\
(\mu \mathrm{S} / \mathrm{cm})\end{array}$ & $\begin{array}{l}\text { 1. Electrical Conductivity } \\
\text { Up; } \\
\text { 2. Plant Roots Growth } \\
\text { Interrupted; } \\
\text { 3. Salt Levels Up. }\end{array}$ & Conductometer \\
\hline \multicolumn{4}{|c|}{ BIOLOGICAL PROPERTIES OF SOIL } \\
\hline No & Parameter & Damage Occurred & $\begin{array}{l}\text { Measurement } \\
\text { methods }\end{array}$ \\
\hline 1 & $\begin{array}{l}\text { carbon } \\
\text { microorganis } \\
\text { ms }\end{array}$ & $\begin{array}{l}\text { 1. Microorganisms Carbon } \\
\text { Down; } \\
\text { 2. Many microorganisms } \\
\text { Dead; } \\
\text { 3. Disturbed Land } \\
\text { Biochemistry reaction. }\end{array}$ & $\begin{array}{l}\text { CFE - TOC or CFE } \\
\text { Walkley and Black. }\end{array}$ \\
\hline 2 & Respiration & $\begin{array}{l}\text { 1. Respiration Down; } \\
\text { 2. Disturbed Soil Chemical } \\
\text { Reactions; } \\
\text { 3. Reduced diversity of } \\
\text { Soil Microorganisms. }\end{array}$ & Jars method. \\
\hline 3 & $\begin{array}{l}\text { metabolic } \\
\text { Quotient } \\
\left(\mathrm{QCO}^{2}\right)\end{array}$ & $\begin{array}{l}\text { 1. metabolic Quotient rose; } \\
\text { 2. Soil microorganisms; } \\
\text { 3. Reduced diversity of } \\
\text { microorganisms. }\end{array}$ & $\begin{array}{l}\text { Respiration and } \\
\text { Carbon Calculation } \\
\text { Of } \\
\text { Microorganisms. }\end{array}$ \\
\hline 4 & $\begin{array}{l}\text { Total } \\
\text { Microorganis } \\
\mathrm{ms}(\mathrm{SPK} / \mathrm{g})\end{array}$ & $\begin{array}{l}\text { 1. Total Microorganisms } \\
\text { Down; } \\
\text { 2. Reduced diversity of } \\
\text { microorganisms. }\end{array}$ & Counting plate. \\
\hline 5 & $\begin{array}{l}\text { Total Function } \\
\text { (SPK / g) }\end{array}$ & $\begin{array}{l}\text { 1. Total Function Down; } \\
\text { 2. Impaired balance } \\
\text { microorganism } \\
\text { population. }\end{array}$ & Counting plate. \\
\hline
\end{tabular}

Table 2. General Criteria Peat Raw Damage Associated With Fire Land. Source Provided by Government Regulation No. 4 of 2001.

\begin{tabular}{|l|l|l|l|}
\hline \multicolumn{3}{|c|}{ PHYSICAL LAND } \\
\hline No & Parameter & Damage Occurred & $\begin{array}{l}\text { Measurement } \\
\text { methods }\end{array}$ \\
\hline 1 & $\begin{array}{l}\text { 1. Decreased occurrence of } \\
\text { porosity; } \\
\text { 2. Pecreased infiltration; }\end{array}$ & $\begin{array}{l}\text { Weight Calculation } \\
\text { Of Moisture } \\
\text { Content and } \\
\text { 3. The increased flow of } \\
\text { surface; } \\
\text { 4. Availability of Air and } \\
\text { Water to Reduce Crop. } \\
\text { Capacity } \\
\text { Retention. }\end{array}$ \\
\hline 2 & $\begin{array}{l}\text { Fill weights (g } \\
\left./ \mathrm{cm}^{3}\right)\end{array}$ & $\begin{array}{l}\text { 1. Compaction occurs; } \\
\text { 2. Plant Roots Not } \\
\text { Evolving; }\end{array}$ & $\begin{array}{l}\text { Ring Plate - } \\
\text { Gravimetry. }\end{array}$ \\
\hline
\end{tabular}

Table 2, cont.

\begin{tabular}{|c|c|c|c|}
\hline & & $\begin{array}{l}\text { 3. Availability of Air and } \\
\text { Water To Reduce Crop }\end{array}$ & \\
\hline 3 & $\begin{array}{l}\text { Available } \\
\text { Water Content } \\
(\%)\end{array}$ & $\begin{array}{l}\text { 1. The decline occurred } \\
\text { Moisture; } \\
\text { 2. Declining Soil Water } \\
\text { Holding Capacity; } \\
\text { 3. Water Shortage plants. }\end{array}$ & $\begin{array}{l}\text { Pressure Plate - } \\
\text { Gravimetry. }\end{array}$ \\
\hline 4 & $\begin{array}{l}\text { Soil } \\
\text { penetration } \\
\left(\mathrm{kg} / \mathrm{cm}^{2}\right)\end{array}$ & $\begin{array}{l}\text { 1. Soil Penetration Rises; } \\
\text { 2. Water infiltration Down; } \\
\text { 3. Plant Roots Not } \\
\text { Evolving. }\end{array}$ & Penetrometer. \\
\hline 5 & Subsidence. & $\begin{array}{l}\text { 1. The decline occurred } \\
\text { Surface Peat; } \\
\text { 2. Declining Soil Effective } \\
\text { depth; }\end{array}$ & $\begin{array}{l}\text { Subsidence stakes } \\
\text { in the Field. }\end{array}$ \\
\hline
\end{tabular}

3. Age Use Land Down

\section{CHEMICAL SOIL PROPERTIES}

\begin{tabular}{|c|c|c|c|}
\hline No & Parameter & Damage Occurred & $\begin{array}{l}\text { Measurement } \\
\text { methods }\end{array}$ \\
\hline 1 & $\begin{array}{l}\mathrm{C} \text { - Organic } \\
(\%)\end{array}$ & $\begin{array}{l}\text { 1. Levels of C - Organic } \\
\text { Land Down; } \\
\text { 2. Soil Fertility Decline. }\end{array}$ & $\begin{array}{l}\text { Walkey and Black } \\
\text { or the CHNS } \\
\text { Elementary } \\
\text { Analysis Tool. }\end{array}$ \\
\hline 2 & N Total (\%) & $\begin{array}{l}\text { 1. Levels of N Total Down; } \\
\text { 2. Soil Fertility Decline. }\end{array}$ & $\begin{array}{l}\text { Kjeldahl or the } \\
\text { CHNS Elementary } \\
\text { Analysis Tool. }\end{array}$ \\
\hline A & $\begin{array}{l}\text { Ammonium } \\
(\mathrm{ppm})\end{array}$ & $\begin{array}{l}\text { 1. Ammonium levels are } \\
\text { down; } \\
\text { 2. Soil Fertility Decline. }\end{array}$ & $\begin{array}{l}\text { Kjeldahl or } \\
\text { Specific Electrodes } \\
\text { or Autoanalisator. }\end{array}$ \\
\hline B & Nitrate (ppm) & $\begin{array}{l}\text { 1. Nitrate Levels Rise; } \\
\text { 2. Groundwater poison. }\end{array}$ & $\begin{array}{l}\text { Kjeldahl or } \\
\text { Specific Electrodes } \\
\text { or Autoanalisator. }\end{array}$ \\
\hline 3 & $\mathrm{P}(\mathrm{ppm})$ & $\begin{array}{l}\text { 1. Available } P \text { content Up; } \\
\text { 2. Nutrient balance } \\
\text { Impaired. }\end{array}$ & $\begin{array}{l}\text { Spectrophotometer } \\
\text { or Autoanalisator. }\end{array}$ \\
\hline 4 & $\mathrm{pH}$ & $\begin{array}{l}\text { 1.pH Up or Down; } \\
\text { 2. Nutrient balance } \\
\text { Impaired. }\end{array}$ & PH meter. \\
\hline 5 & $\begin{array}{l}\text { Electrical } \\
\text { conductivity } \\
(\mu \mathrm{S} / \mathrm{cm})\end{array}$ & $\begin{array}{l}\text { 1. Electrical Conductivity } \\
\text { Up; } \\
\text { 2. Plant Roots Growth } \\
\text { Interrupted; } \\
\text { 3. Salt Levels Up. }\end{array}$ & Conductometer. \\
\hline \multicolumn{4}{|c|}{ BIOLOGICAL PROPERTIES OF SOIL } \\
\hline No & Parameter & Damage Occurred & $\begin{array}{l}\text { Measurement } \\
\text { methods }\end{array}$ \\
\hline 1 & $\begin{array}{l}\text { carbon } \\
\text { Microorganis } \\
\mathrm{ms}\end{array}$ & $\begin{array}{l}\text { 1. Microorganisms Carbon } \\
\text { Down; } \\
\text { 2. Many microorganisms } \\
\text { Dead; } \\
\text { 3. Disturbed Soil } \\
\text { Biochemical reactions. }\end{array}$ & $\begin{array}{l}\text { CFE - TOC or CFE } \\
\text { Walkley and Black. }\end{array}$ \\
\hline 2 & Respiration & $\begin{array}{l}\text { 1. Respiration Down; } \\
\text { 2. Disturbed Soil Chemical } \\
\text { Reactions; } \\
\text { 3. Reduced diversity of } \\
\text { Soil Microorganisms. }\end{array}$ & Jars method. \\
\hline 3 & $\begin{array}{l}\text { metabolic } \\
\text { Quotient } \\
\left(\mathrm{QCO}^{2}\right)\end{array}$ & $\begin{array}{l}\text { 1. metabolic Quotient rose; } \\
\text { 2. Soil microorganisms; } \\
\text { 3. Reduced diversity of } \\
\text { microorganisms. }\end{array}$ & $\begin{array}{l}\text { Respiration and } \\
\text { Carbon Calculation } \\
\text { Of } \\
\text { Microorganisms. }\end{array}$ \\
\hline 4 & $\begin{array}{l}\text { Total } \\
\text { Microorganis } \\
\mathrm{ms}(\mathrm{SPK} / \mathrm{g})\end{array}$ & $\begin{array}{l}\text { 1. Total Microorganisms } \\
\text { Down; } \\
\text { 2. Reduced diversity of } \\
\text { microorganisms. } \\
\end{array}$ & Counting plate. \\
\hline 5 & $\begin{array}{l}\text { Total Function } \\
\text { (SPK / g) }\end{array}$ & $\begin{array}{l}\text { 1. Total Function Down; } \\
\text { 2. Impaired balance } \\
\text { microorganism } \\
\text { population. }\end{array}$ & Counting plate. \\
\hline
\end{tabular}


Table 3. Common Criteria Raw Flora Damage Associated With Fire Land. Source Provided by Government Regulation No. 4 of 2001

\begin{tabular}{|l|l|l|l|}
\hline No & Parameter & Damage Occurred & $\begin{array}{l}\text { Measurement } \\
\text { methods }\end{array}$ \\
\hline \multirow{1}{*}{1} & $\begin{array}{l}\text { Species } \\
\text { diversity }\end{array}$ & $\begin{array}{l}\text { Decurrence of Change } \\
\text { 2. Occurrence Reduction and } \\
\text { Addition of Varieties; } \\
\text { 3. The occurrence of species } \\
\text { extinction; } \\
\text { 4. The ecosystem imbalance. }\end{array}$ & Sampling. \\
\hline 2 & Population & $\begin{array}{l}\text { 1. Density Changes occur; } \\
\text { 2. Population changes occur; } \\
\text { 3.Ecosystem imbalance } \\
\text { occurs. }\end{array}$ & Sampling. \\
\hline
\end{tabular}

Table 4. General Criteria Baku Fauna Damage Dealt With Fire Land. Source Provided by Government Regulation No. 4 of 2001.

\begin{tabular}{|c|c|c|c|}
\hline No & Parameter & Damage Occurred & $\begin{array}{l}\text { Measurement } \\
\text { methods }\end{array}$ \\
\hline 1 & $\begin{array}{l}\text { Species } \\
\text { diversity }\end{array}$ & $\begin{array}{l}\text { 1. Changes occur Diversity; } \\
\text { 2. Behavior Changes occur; } \\
\text { 3. Reduction and Addition } \\
\text { Varieties occur; } \\
\text { 4. Species Extinction } \\
\text { occurred; } \\
\text { 5. Ecosystem imbalance } \\
\text { occurs. }\end{array}$ & Sampling. \\
\hline 2 & Population & $\begin{array}{l}\text { 1. Density Changes occur; } \\
\text { 2. Behavior Changes occur; } \\
\text { 3. Population changes occur; } \\
\text { 4. Ecosystem imbalance } \\
\text { occurs. }\end{array}$ & Sampling. \\
\hline
\end{tabular}

Pollution damage which exceeded the standard criteria would result in environmental damage. Under the provisions of Article 88 of Law No. 32 of 2009 and Article 49 of Law No. 41 of 1999, which applied for corporate accountability as a result of the occurrence of forest fires that cause pollution beyond the standard criteria for damage resulting environmental damage is an absolute liability.

Assessed by the Civil Code, the corporate forest fires that cause pollution beyond the standard criteria for damage resulting environmental damage is Act against the Law, where one of the elements that must be proven is the element of fault.

In the case of a corporation applicable absolute responsibility for his mistakes in the form of occurrence of forest fires that cause pollution beyond the standard criteria for damage resulting from environmental damage, of course, the implementation of such accountability has accommodated equitable principle of legal certainty.

Conversely in the case of a corporation applicable liability absolute no fault, of course, it was contrary to the provisions of Article 28 D Paragraph (1) of the 1945 Constitution and Article 1365 of the Civil Code, so it can be confirmed that Article 88 of Law No. 32 of 2009 and Article 49 of Law No. 41 of 1999 is the legal norms that do not accommodate the principle of legal certainty fair.

Based on existing exposure, it can be affirmed that in fact there is a discrepancy and disharmony between the provisions of 28 D paragraph (1) of the 1945 Constitution and Article 1365 of the Civil Code with the provisions of Article 88 of Law No. 32 of 2009 and Article 49 of Law No. 41 of 1999. However, of course, there is the rationale the application of absolute liability for the corporation as a result of the forest fires that cause pollution.

One element of a constitutional state is the recognition and protection of human rights. Protection is designated legal protection. Based on the Theory of Legal Protection by Fitzgerald, legal protection for the interests of a party may be given by way of limitation various interests on the other side. Legal interest is none other than to deal with the human rights and interests by the legal provisions outlined in the various legislation [16].

The legal protection of human rights must be able to protect the affected communities, and given that the public could enjoy all the rights that the law was adopted. Legal protection is not just to be adaptive and flexible, but also to be predictive and anticipatory. Law is needed for humans are weak and not strong socially, economically, and politically, so that a weak man can obtain social justice as it has been mandated V precepts of Pancasila [17].

As the law states, Indonesia also recognizes and protects human rights. Under the provisions of Article $28 \mathrm{H}$ paragraph (1) of the 1945 Constitution and the provisions of Article 9 paragraph (3) of Act No. 39 of 1999 on Human Rights (Act No. 39 of 1999), the right to a healthy environment and health is a human rights for everyone citizen [18].

Laws must be enforced. Law enforcement is harmonious relationship values that have been outlined in the norms, steady gaze and embodied in attitude acts as a series of translation of the value of the final stages to create peace in social life [19].

Law enforcement is the implementation of an idea or concept of justice, legal certainty, usefulness, and even truth. Through law enforcement, then the idea or concept of justice, legal certainty, usefulness, and even truth becomes a reality. With the implementation of the law, not automatically mean there has also been human rights enforcement.

Law enforcement includes a variety of fields, one of which is the area of environmental law [20]. To that end, the various provisions contained in Law No. 32 of 2009 and other laws and regulations relating to the environment, must be enforced [21].

In law, there are an essential and basic elements, namely the principle. The principle is the ratio legitimate of various laws. The position of principle in law is a state of mind which is the background in the formation of the different norms of law [22]. Laws must not be understood without principle. The principle is the symptom that directs human morality to the law [23].

In Act No. 32 of 2009 also has loaded a variety of principles. Principles relating to the application of absolute liability for the corporation as a result of the occurrence of forest fires that cause pollution are the principle of national responsibility, and the polluter pays principle, as set out in Article 2 letter a and j Act No. 32 of 2009 [24].

Based on the exposure that has been there, it can be affirmed that the rationale for the application of absolute liability for the corporation as a result of the occurrence of forest fires that cause pollution are: first, the implementation 
of the recognition and protection of human rights in the environmental field; and secondly, the application of the principle of national responsibility and the polluter pays principle specified in Article 2 letter a and j Act No. 32 of 2009.

One purpose of the law is the benefit [25]. Expediency theory teaches a law is considered safe in bringing happiness; otherwise, an act is not considered good if it brings unhappiness. Expediency doctrinal theory of consequentialism as the final orientation of law is a benefit [26].

Thinker Jeremy Bentham regarded as a complete and comprehensive utilitarianism because he has been able to formulate and popularize the Expediency theory [27]. Jeremy Bentham utilitarianism initiated as part of the ethical system [28]. Ethical quality of an act can be assessed based on the achievement of objectives of good works, which would base the benchmark is the result of expediency, which, if not useful, then it certainly does not deserve categorized as good [29].

Utilitarianism seeks to create sustainable development [30], which emphasizes the collected wisdom to prosper [31]. John Stuart Mill successfully Expediency elaboration and development theory. Criteria benefits according to John Stuart Mill is a prosperous state if able to show the individual more resistant as a result of the desired [32].

The principle benefit could be used to justify the law as an instrument of state control for the public interest and to achieve happiness. Therefore, it can be enforced compulsion for everyone to prevent doing damage and harm others in the search for individual happiness or group, by countries restrict the rights and obligations of each person in the legislation.

Has been described previously that under the provisions of Article 88 of Law No. 32 of 2009 and Article 49 of Law No. 41 of 1999, which applied for corporate accountability as a result of the occurrence of forest fires that cause pollution beyond the standard criteria for damage resulting environmental damage is an absolute liability.

The benefits of the application of absolute responsibility for the corporation as a consequence of the occurrence of forest fires that cause pollution are: first, every society that controls forests and plantations fulfill the obligation to sustain environmental functions; second, with compensation given corporation due to the forest fires that cause pollution, the Government through KLHK can restore the state of people and the polluted environment [33].

\section{CONCLUSION}

The rationale for the implementation of the accountability essential for the corporation as a result of the occurrence of forest fires that cause pollution are the application of the recognition and protection of human rights in the environmental field, as well as the implementation of the principle of national responsibility and the principle of the polluter pays specified in Article 2 letter a and $\mathrm{j}$ Law Number 32 the year 2009 .

Benefits of the application of absolute liability for the corporation as a result of the occurrence of forest fires that cause pollution is every corporation carrying out the obligation to maintain the sustainability of environmental functions, as well as with compensation granted government corporation can restore the state of people and polluted environment.

\section{REFERENCES}

[1] Alvi Syahrin, Beberapa Masalah Hukum, Medan: Sofmedia, 2009, pp. 2-3. Law becomes significant socially when human behavior is "influenced" by law and when people make use of law in purposive conduct. Franz yon Benda-Beckmann, Why Does not Behave - Critical and Constructive Reflection on The Social Scientific Perception of The Social Significance of Law, Canada: Vancouver, Xith International Congress of IUEAS, 1983, pp. 1.

[2] Philippe Nonet dan Philip Selznick, Law, and Society in Transition, Newyork, Toward Responsive Law, Harper \& Row, 1978, pp.3. Lawrence M. Friedman, Law and Society: An Introduction: New Jersey: Prentice-Hall Inc., Englewood Cliffs, 1977, pp. 168.

[3] M. Yahya Harahap, Beberapa Tinjauan Tentang Permasalahan Hukum, Bandung: Citra Aditya Bakti, 1997, pp. 54.

[4] Pasal 28 H ayat (1) UUD 1945.

[5] Korporasi merupakan kumpulan yang terorganisasi dari orang dan/atau kekayaan baik yang berbadan hukum maupun bukan. Alvi Syahrin, Beberapa Isu Hukum Lingkungan Kepidanaan, Medan: Sofmedia, 2009, pp. 27. Di dalam hukum, istilah person mencakup mahluk pribadi, yakni manusia dan badan hukum. Keduanya adalah subjek hukum, sehingga keduanya merupakan drager van het recht en plicht. Ridwan Khairandy, Perseroan Terbatas: Doktrin, Peraturan Perundang-undangan, dan Yurisprudensi, Yogyakarta: Total Media, 2009, pp. 4. Badan memiliki kewajiban layaknya manusia. Robert W. Hamilton, The Law of Corporation, St. Paul, Minn: West Publishing Co, 1996, pp. 1.

[6] Pasal 68 huruf b UU Nomor 32 Tahun 2009.

[7] Pasal 1 ayat (14) UU Nomor 32 Tahun 2009.

[8] Pasal 1 ayat (15) dan ayat (17) UU Nomor 32 Tahun 2009.

[9] Pasal 88 UU Nomor 32 Tahun 2009. pula Pasal 49 UU Nomor 41 Tahun 1999.

[10] Pasal 1365 KUH Perdata.

[11] Pasal 28 D ayat (1) UUD 1945.

[12] Penelitian hukum normatif dapat didefinisikan sebagai penelitian yang berdasarkan berbagai norma hukum dalam peraturan perundangundangan dan maupun berbagai putusan pengadilan. Ronny Hanitijo Soemitro, Metodologi Penelitian Hukum dan Jurimetri, Jakarta: Ghalia Indonesia, 1988, pp. 10.

[13] Metode yuridis normatif beracuan pada norma hukum dalam berbagai peraturan perundang-undangan. Soerjono Soekanto, dan Sri Mamuji, Penelitian Hukum Normatif, Jakarta: Raja Grafindo Persada, 2004, pp. 10.

[14] Soerjono Soekanto, Pengantar Penelitian Hukum, Jakarta: Universitas Indonesia Press, 1986, pp. 51. Dalam penelitian hukum dikenal data primer dan data sekunder. Data primer didapatkan langsung dari lapangan, sedangkan data sekunder adalah didapatkan dari bahan pustaka. Bambang Sunggono, Penelitian Hukum: Suatu Pengantar, Jakarta, Raja Grafindo Persada, 2002, pp. 194-195.

[15] I Dewa Gede Atmadja, Hukum Konstitusi: Problematik Konstitusi Indonesia Sesudah Perubahan UUD NRI 1945, Malang: Setara Press, 2010, pp. 159.

[16] Satjipto Rahardjo, Ilmu Hukum, Bandung: Citra Aditya Bakti, 2000, pp.54.

[17] Ibid, pp. 55.

[18] Pasal 9 ayat (3) UU Nomor 39 Tahun 1999.

[19] Soerjono Soekanto, Beberapa Permasalahan Hukum Dalam Kerangka Pembangunan di Indonesia, Jakarta: Universitas Indonesia Press, 1983, pp.3.

[20] Hukum Lingkungan merupakan bagian Hukum Administrasi, dan juga mengandung aspek Hukum Pajak, Hukum Internasional, Hukum Penataan Ruang, Hukum Perdata, Hukum Pidana, serta tidak dapat digolongkan dalam pembidangan hukum klasik. Siti Sundari Rangkuti, 
Hukum Lingkungan dan Kebijaksanaan Lingkungan Nasional, Surabaya: Airlangga University Press, 1996, pp. 3-4.

[21] Sifat dan wataknya Hukum Lingkungan banyak beracuan kepada ekologi, sehingga berorientasi kepada lingkungan. Ini menunjukkan, Hukum Lingkungan memiliki sifat utuh-menyeluruh, yang senantiasa dinamika dengan sifat serta watak yang luwes. pula Koesnadi Hardjasoemantri, Hukum Tata Lingkungan, Yogyakarta, Gajah Mada University Press, 1997, pp. 32-33.

[22] Mahadi, Falsafah Hukum Suatu Pengantar, Bandung, Citra Aditya, 1989, pp. 122.

[23] John Z. Loudoe, Menemukan Hukum Melalui Tafsir dan Fakta, Jakarta: Bina Aksara, 1985, pp. 127.

[24] penjelasan Pasal 2 huruf a dan j UU Nomor 32 Tahun 2009.

[25] Kemanfaatan sebagai tujuan utama dari hukum dimaknai sebagai kebahagiaan atau kesenangan (happiness). Penekanannya bukan masalah adil atau tidak adil, tetapi sampai sejauh mana hukum dapat memberikan kebahagiaan kepada manusia atau tidak. Zainuddin Ali, Filsafat Hukum, Jakarta: Sinar Grafika, 2010, pp. 59.

[26] Atip Latipulhayat, Kahzanah Jeremy Bentham, Bandung: Padjadjaran Jurnal Ilmu Hukum, Vol. 2, No.2, 2015, pp. 413.

[27] Ruth Borchard, John Stuart Mill: The Man, London; Watts, 1957, pp. 12.

[28] Atip Latipulhayat, Op.cit., pp. 415. Secara umum sistem etika dibagi 2, yakni teleologis (berorientasi pada tujuan) dan deontologi (berorientasi pada kewajiban). Berdasarkan sistem etika teleologis, baik atau tidakn baikya suatu perbuatan diukur berdasarkan konsekuensinya, karena itu sistem ini disebut juga konsekuensialisme yang salah satu alirannya adalah utilitarianisme.

[29] K. Bertens, Pengantar Etika Bisnis, Yogyakarta: Kanisius, 2000, pp. 67.

[30] Ibid, pp. 66.

[31] John Rawls, A Theory of Justice, London: Harvard University Press, 1971, pp. 23-24.

[32] Gunawan Prasetio, Etika Bisnis, Yogyakarta: Simon \& Schuster, 1997, pp. 190-192.

[33] Berdasarkan Teori Corrective Justice, setiap orang haruslah dilindungi haknya dan dipulihkan pula keadaannya (seperti semula sebelum PMH itu terjadi) agar ada keseimbangan antara keadilan dan kepastian hukum yang merupakan tujuan hukum. pula Rosa Agustina, Perbuatan Melawan Hukum, Jakarta: Disertasi, Program Pasca Sarjana, Fakultas Hukum, Universitas Indonesia, 2003, pp. 91-96 